\title{
Comparison between in situ dry matter degradation and in vitro gas production of tannin-containing leaves from four tree species
}

\author{
A. Kamalak ${ }^{1}$, O. Canbolat $^{2}$ and Y. Gurbuz ${ }^{1}$ \\ ${ }^{1}$ Kahramanmaras Sutcu, Imam University, Faculty of Agriculture, Department of Animal Science \\ 46100 Kahramanmaras, Turkey \\ ${ }^{2}$ Bursa Uludag University, Faculty of Agriculture, Department of Animal Nutrition, Bursa, Turkey
}

\begin{abstract}
Dry matter (DM) degradation of Glycrrhiza glabra L, Arbutus andrachne, Juniperus communis, and Pistica lentiscus was determined using two different techniques: (i) the in vitro gas production and (ii) the in situ nylon bag degradability technique. Samples were incubated in situ and in vitro for 3, 6, 12, 24, 48, 72 and $96 \mathrm{~h}$. In situ and in vitro DM degradation kinetics were described using the equation y $=\mathrm{a}+\mathrm{b}\left(1-\mathrm{e}^{\mathrm{ct}}\right)$. At all incubation times except 3 and $72 \mathrm{~h}$ the cumulative gas production of $J$. communis was significantly lower than that of G. glabra, A. andrachne and P. lentiscus. At 3, 6 and $12 \mathrm{~h}$ incubation times the DM disappearance of $J$. communis was only significantly lower than that of P. lentiscus. At 24 and $48 \mathrm{~h}$ incubation times DM disappearance of $J$. communis was significantly lower than that of $A$. andrachne and $P$. lentiscus. There were significant relationships between in vitro gas production and in situ DM disappearance at $24 \mathrm{~h}$ and $96 \mathrm{~h}$ incubation times. The gas productions at 24 and $96 \mathrm{~h}$ incubation explained 51.2 and 52.4\% of variation of DM disappearance, respectively. Gas production from the insoluble fraction (b) alone explained $66.4 \%$ of the variation of effective DM degradability (EDMD). The inclusion of gas production from quickly soluble fraction (a) and rate constant (c) of gas production in the regression equation did not improve the accuracy of predicting EDMD. It was concluded that in situ DM disappearance parameters of tannin-containing tree leaves such as used in this present study may be predicted from in vitro gas production parameters.
\end{abstract}

Keywords: Tree leaves, in situ dry matter degradation, in vitro gas production, tannin

${ }^{\#}$ Corresponding author. E-mail: akamalak@ksu.edu.tr

\section{Introduction}

The use of browse species as fodder for ruminant animals is becoming important in many parts of the world. The presence of tannins and other phenolic compounds in a large number of nutritionally important shrubs and tree leaves hampers their utilization as animal feed (Tolera et al., 1997). However, the information about the fermentation kinetics of tannin containing tree leaves is limited.

The rate and extent of fermentation of dry matter (DM) in the rumen are very important determinants for the nutrients absorbed by ruminants. The nylon bag technique has been used for many years to provide an estimate of both rate and extent of DM degradation of forages in situ (Mehrez \& Ørskov, 1977). On the other hand, Menke et al. (1979) and Menke \& Steingass (1988) developed the in vitro gas production technique to evaluate the nutritive value of forages and estimate the rate and extent of DM degradation indirectly using the gas production $\left(\mathrm{CO}_{2}\right)$ during fermentation. The in situ nylon bag and in vitro gas production technique are well correlated with animal performance (Ørskov, 1989), food intake (Blummel \& Ørskov, 1993), microbial protein synthesis (Krishnamoorthy et al., 1991) and in vivo digestibility (Khazaal et al., 1993). More recently researchers have been investigating the relationship between fermentation kinetics of forages obtained by the in situ nylon bag technique and the in vitro gas production technique (Blummel \& Ørskov, 1993; Khazaal et al., 1993; Dewhurst et al., 1995).

The aim of this study was to (I) determine fermentation kinetics of tannin containing tree leaves using the in vitro gas production and in situ nylon bag technique and (II) to determine whether it is possible to predict in situ DM degradability with the in vitro gas production technique.

\section{Materials and Methods}

Leaves from Glycrrhiza glabra L, Arbutus andrachne, Juniperus communis and Pistica lentiscus were harvested in the dry season (August, September and October) in the vicinity of the city, Kahramanmaras, in 
the south of Turkey. The area is located at an altitude of $630 \mathrm{~m}$ above sea level. The mean annual rainfall and temperature are $857.5 \mathrm{~mm}$ and $16.2^{\circ} \mathrm{C}$, respectively. Leaves were hand harvested from at least 10 different trees, then pooled and oven dried at $60{ }^{\circ} \mathrm{C}$ for $48 \mathrm{~h}$ (Abdulrazak et al., 2000).

All chemical analyses were carried out in triplicate. Dry matter was determined by drying the samples at $105{ }^{\circ} \mathrm{C}$ overnight and ash by igniting the samples in a muffle furnace at $525^{\circ} \mathrm{C}$ for $8 \mathrm{~h}$. Nitrogen (N) content was measured by the Kjeldahl method (AOAC, 1990). Crude protein was calculated as N x 6.25. Concentrations of neutral detergent fibre (NDF) and acid detergent fibre (ADF) of leave samples were determined by the method of Van Soest et al. (1991). Total condensed tannin, bound condensed tannin and soluble condensed tannin were determined by the butanol-HCl method as described by Makkar et al. (1995). Mimosa tannin (MT; Hodgson, England) was used as an external standard.

Forage samples, milled through a $1 \mathrm{~mm}$ sieve, were incubated in rumen fluid in calibrated glass syringes, following the procedures of Menke \& Steingass (1988). Rumen fluid was obtained from three fistulated sheep fed twice daily on a diet containing lucerne hay (60\%) and concentrate (40\%). Dry samples $(0.2 \mathrm{~g})$ were weighed in triplicate into calibrated glass syringes of $100 \mathrm{~mL}$. The syringes were prewarmed at $39{ }^{\circ} \mathrm{C}$ before the injection of $30 \mathrm{~mL}$ rumen fluid-buffer mixture into each syringe followed by incubation in a water bath at $39^{\circ} \mathrm{C}$. Readings of gas production were recorded before incubation (0) and 3, 6, 12, 24, 48, 72 and $96 \mathrm{~h}$ after incubation. Total gas values were corrected for blank incubation. Cumulative gas production data were fitted to the exponential equation: $\mathrm{p}=\mathrm{a}+\mathrm{b}\left(1-\mathrm{e}^{-\mathrm{ct}}\right)$ (Ørskov \& McDonald, 1979):

where $\mathrm{p}$ is the gas production at time $\mathrm{t}$; $\mathrm{a}$ is the gas production from the immediately soluble fraction $(\mathrm{mL}), \mathrm{b}$ is the gas production from the insoluble fraction $(\mathrm{mL}), \mathrm{c}$ is the gas production rate constant, $\mathrm{a}+\mathrm{b}=\mathrm{the}$ potential gas production $(\mathrm{mL}), \mathrm{t}=$ incubation time $(\mathrm{h})$.

The in situ DM degradation analysis was carried out according to the procedure described by Mehrez \& Ørskov (1977). Five gram samples dried and milled through a $3 \mathrm{~mm}$ sieve were weighed into nylon bags and incubated for 3, 6, 12, 24, 48, 72 and $96 \mathrm{~h}$ in three rumen fistulated sheep. A completely randomized block design was used. The sheep were fed twice a day on a $60 \%$ lucerne hay and $40 \%$ concentrate diet. After removal, the nylon bags were thoroughly washed with running cold water until no further coloured liquid could be extruded, and dried at $60{ }^{\circ} \mathrm{C}$ for $48 \mathrm{~h}$. Dry matter losses for each incubation time were determined. The DM degradation data were fitted to the exponential equation $\mathrm{p}=\mathrm{a}+\mathrm{b}\left(1-\mathrm{e}^{-\mathrm{ct}}\right.$ ) (Ørskov \& McDonald (1979): where $\mathrm{p}$ is DM disappearance in rumen at time $\mathrm{t}$, a is the rapidly soluble fraction, $\mathrm{b}$ is the insoluble but fermentable fraction, $c$ = the constant rate of degradation of b (percentage per h). Effective DM degradability (EDMD) was calculated applying the equation of Ørskov \& McDonald (1979): EDMD = a + (bc / (c+k)), where $\mathrm{k}$ is the rumen outflow rate of $2 \%$ per $\mathrm{h}$, which is at the maintenance level.

Analysis of variance (ANOVA) was carried out for in vitro gas production, in situ DM disappearance and estimated parameters using General Linear Model (GLM) of Statistica for Windows (1993). The experiment was not replicated at field harvesting. Therefore tree species were not compared in terms of chemical composition. A complete randomized block design for in situ DM degradation was used. Because of the differences between the sheep, each sheep was considered as a block and the tree species were fixed factors in the linear model.

Significant differences between individual means were identified using the Tukey's Multiple Range Test (Pearse \& Hartley, 1966). Mean differences were considered significant at $\mathrm{P}<0.05$. Standard errors of means were calculated from the residual mean square in the analysis of variance. A simple correlation analysis was used to establish the relationship between chemical composition, in situ DM degradation and in vitro gas production.

\section{Results}

The proximate composition and condensed tannin concentration of the tree leaves are presented in Table 1. Generally there were considerable variations between tree and shrub leaves in terms of chemical compositions. The CP concentration of tree leaves ranged from 72.5 to $125.9 \mathrm{~g} / \mathrm{kg} \mathrm{DM}$. The ash level of leaves ranged from 65.9 to $78.9 \mathrm{~g} / \mathrm{kg}$ DM. The NDF and ADF levels ranged from 343.7 to $571.7 \mathrm{~g} / \mathrm{kg} \mathrm{DM}$ and from 251.7 to $333.5 \mathrm{~g} / \mathrm{kg}$ DM, respectively.

Data on gas production during the fermentation period are given in Table 2. The cumulative volume of gas production increased with increasing time of incubation. Gas produced after $96 \mathrm{~h}$ incubation ranged between 61.84 and $73.55 \mathrm{~mL}$ per $0.2 \mathrm{~g}$ of substrate. 
At all incubation times the cumulative gas production of $J$. communis was lower $(\mathrm{P}<0.001)$ than that of G. glabra, A. andrachne and P. lentiscus except at the 3 and $72 \mathrm{~h}$ incubations. Therefore, the estimated parameters (constant a, b and a+b) of J. communis are lower $(\mathrm{P}<0.001)$ than those of G. glabra, A. andrachne and P. lentiscus whereas the gas production rate (c) of $\mathrm{b}$ for $J$. communis was lower $(\mathrm{P}<0.01)$ than that of G. glabra and A. andrachne.

Table 1 Mean chemical composition (g/kg DM) of leaves from different trees

\begin{tabular}{lcccc}
\hline & \multicolumn{4}{c}{ Tree species } \\
\cline { 2 - 5 } & Glycyrrhiza glabra & Arbutus andrachne & Juniperus communis & Pistica lentiscus \\
\hline Dry matter & 929.1 & 959.3 & 948.2 & 956.1 \\
Ash & 78.9 & 65.9 & 77.0 & 72.0 \\
Crude protein & 125.9 & 72.5 & 107.3 & 95.0 \\
Neutral detergent fibre & 343.7 & 348.7 & 571.7 & 431.7 \\
Acid detergent fibre & 251.5 & 319.7 & 333.5 & 305.8 \\
Total condensed tannin & 126.6 & 120.4 & 197.0 & 156.9 \\
Bound condensed tannin & 85.5 & 30.0 & 170.0 & 23.5 \\
Soluble condensed tannin & 41.0 & 93.0 & 26.9 & 130.9 \\
\hline
\end{tabular}

Table 2 In vitro gas production $(\mathrm{mL})$ and estimated parameters of leaves from different trees when incubated with buffered rumen liquid

\begin{tabular}{|c|c|c|c|c|c|c|c|}
\hline \multirow[b]{2}{*}{ Tree species } & \multicolumn{7}{|c|}{ Incubation times (h) } \\
\hline & 3 & 6 & 12 & 24 & 48 & 72 & 96 \\
\hline G. glabra & $21.8^{\mathrm{C}}$ & $35.2^{\mathrm{c}}$ & $45.2^{b}$ & $55.0^{b}$ & $64.9^{b}$ & $69.9^{b}$ & $73.6^{b}$ \\
\hline A. andrachne & $20.3^{\mathrm{bc}}$ & $30.7^{\mathrm{bc}}$ & $41.9^{\mathrm{b}}$ & $52.9^{b}$ & $59.9^{\mathrm{a}}$ & $65.3^{\mathrm{a}}$ & $69.8^{b}$ \\
\hline J. communis & $15.1^{\mathrm{a}}$ & $25.0^{\mathrm{a}}$ & $36.3^{\mathrm{a}}$ & $46.6^{\mathrm{a}}$ & $56.5^{\mathrm{a}}$ & $61.4^{\mathrm{a}}$ & $61.8^{\mathrm{a}}$ \\
\hline P. lentiscus & $18.0^{\mathrm{ab}}$ & $29.7^{\mathrm{b}}$ & $42.7^{\mathrm{b}}$ & $55.00^{\mathrm{b}}$ & $65.4^{b}$ & $69.9^{b}$ & $72.3^{b}$ \\
\hline s.e.m. & 0.85 & 1.03 & 1.16 & 0.61 & 0.96 & 1.02 & 1.07 \\
\hline \multirow[t]{3}{*}{ Sig. } & $* * *$ & $* * *$ & $* * *$ & $* * *$ & $* * *$ & $* * *$ & $* * *$ \\
\hline & \multicolumn{7}{|c|}{ Estimated parameters } \\
\hline & \multicolumn{2}{|c|}{ C } & \multicolumn{2}{|c|}{$\frac{a}{3 a b^{b}}$} & $\mathrm{~b}$ & \multicolumn{2}{|r|}{$\mathrm{a}+\mathrm{b}$} \\
\hline G. glabra & \multicolumn{2}{|c|}{$0.087^{b}$} & \multicolumn{2}{|c|}{$3.83^{b}$} & $64.9^{c}$ & \multicolumn{2}{|r|}{$68.8^{\mathrm{C}}$} \\
\hline A. andrachne & \multicolumn{2}{|c|}{$0.084^{\mathrm{b}}$} & \multicolumn{2}{|c|}{$3.37^{b}$} & $61.4^{\mathrm{b}}$ & \multicolumn{2}{|r|}{$64.8^{\mathrm{b}}$} \\
\hline J. communis & \multicolumn{2}{|c|}{$0.070^{\mathrm{a}}$} & \multicolumn{2}{|c|}{$2.21^{b}$} & $57.9^{\mathrm{a}}$ & \multicolumn{2}{|r|}{$60.34^{\mathrm{a}}$} \\
\hline P. lentiscus & \multicolumn{2}{|c|}{$0.075^{\mathrm{ab}}$} & \multicolumn{2}{|c|}{$3.13^{\mathrm{ab}}$} & $66.8^{c}$ & \multicolumn{2}{|r|}{$70.00^{c}$} \\
\hline s.e.m. & \multicolumn{2}{|c|}{0.003} & \multicolumn{2}{|c|}{0.240} & 0.64 & \multicolumn{2}{|r|}{0.76} \\
\hline Sig. & \multicolumn{2}{|c|}{$* *$} & \multicolumn{2}{|c|}{$* *$} & $* * *$ & \multicolumn{2}{|r|}{$* * *$} \\
\hline
\end{tabular}

a c c Column means with common superscripts do not differ ( $>$ > 0.05); s.e.m. - standard error mean; Sig. - significance level; c - gas production rate (\%); a - gas production $(\mathrm{mL})$ from quickly soluble fraction; b - gas production $(\mathrm{mL})$ from the insoluble fraction; $\mathrm{a}+\mathrm{b}$ - potential gas production $(\mathrm{mL})$

$* * * \mathrm{P}<0.001 ; * * \mathrm{P}<0.01$

Data of DM disappearance from nylon bags during the fermentation periods are given in Table 3. The disappearance of DM increased with increasing time of incubation. The DM disappearance after $96 \mathrm{~h}$ incubation ranged between 70.7 and $77.6 \%$.

After 3, 6 and $12 \mathrm{~h}$ incubation, the DM disappearance of $J$. communis was lower $(\mathrm{P}<0.05)$ only to that of $P$. lentiscus. After 24 and $48 \mathrm{~h}$ incubation the DM disappearance of $J$. communis was lower $(\mathrm{P}<0.01)$ than that of Arbutus andrachne and Pistica lentiscus. After $96 \mathrm{~h}$ incubation the DM disappearance of $J$. communis was lower $(\mathrm{P}<0.001)$ than that of G. glabra, A. andrachne and P. lentiscus. The rate of DM disappearance of $P$. lentiscus was higher $(\mathrm{P}<0.05)$ than the others. There were no significant $(\mathrm{P}>0.05)$ differences between tree leaves in terms of the quickly soluble fraction (a) whereas fraction $b$ of $A$. andrachne was higher $(\mathrm{P}<0.05)$ than the others. The EDMD of $J$. communis was lower $(\mathrm{P}<0.001)$ than that of A. andrachne and P. lentiscus. 
Table 3 In situ dry matter disappearance and estimated parameters of leaves from different trees when incubated within rumen

\begin{tabular}{|c|c|c|c|c|c|c|c|}
\hline \multirow[b]{2}{*}{ Tree species } & \multicolumn{7}{|c|}{ Incubation times (h) } \\
\hline & 3 & 6 & 12 & 24 & 48 & 72 & 96 \\
\hline G. glabra & $26.7^{\mathrm{ab}}$ & $35.7^{\mathrm{a}}$ & $47.7^{\mathrm{ab}}$ & $56.6^{\mathrm{a}}$ & $66.5^{\mathrm{ab}}$ & $71.3^{\mathrm{ab}}$ & $75.1^{b}$ \\
\hline A. andrachne & $27.5^{b}$ & $38.6^{a b}$ & $45.9^{\mathrm{ab}}$ & $59.2^{\mathrm{ab}}$ & $69.4^{\mathrm{b}}$ & $73.0^{\mathrm{ab}}$ & $77.6^{\mathrm{b}}$ \\
\hline J. communis & $25.4^{\mathrm{a}}$ & $34.3^{\mathrm{a}}$ & $43.2^{\mathrm{a}}$ & $53.9^{\mathrm{a}}$ & $63.6^{\mathrm{a}}$ & $69.2^{\mathrm{a}}$ & $70.7^{\mathrm{a}}$ \\
\hline P. lentiscus & $29.3^{c}$ & $41.9^{b}$ & $54.0^{\mathrm{b}}$ & $63.4^{\mathrm{b}}$ & $70.1^{\mathrm{b}}$ & $74.6^{\mathrm{b}}$ & $77.2^{\mathrm{b}}$ \\
\hline s.e.m. & 0.33 & 1.07 & 2.09 & 1.22 & 0.86 & 0.99 & 0.62 \\
\hline \multirow[t]{3}{*}{ Sig. } & $* * *$ & $* *$ & $*$ & $* *$ & $* *$ & $* *$ & $* * *$ \\
\hline & \multicolumn{7}{|c|}{ Estimated parameters } \\
\hline & \multicolumn{2}{|c|}{$\mathrm{C}$} & \multicolumn{2}{|c|}{$\mathrm{a}$} & \multicolumn{2}{|c|}{$\mathrm{b}$} & EDMD \\
\hline G. glabra & \multicolumn{2}{|c|}{$0.038^{\mathrm{a}}$} & \multicolumn{2}{|c|}{23.4} & \multicolumn{2}{|c|}{$52.2^{\mathrm{ab}}$} & $57.6^{\mathrm{ab}}$ \\
\hline A. andrachne & \multicolumn{2}{|c|}{$0.035^{\mathrm{a}}$} & \multicolumn{2}{|c|}{24.3} & \multicolumn{2}{|c|}{$56.6^{\mathrm{b}}$} & $59.2^{\mathrm{bc}}$ \\
\hline J. communis & \multicolumn{2}{|c|}{$0.034^{\mathrm{a}}$} & \multicolumn{2}{|c|}{23.1} & \multicolumn{2}{|c|}{$50.0^{\mathrm{a}}$} & $54.8^{\mathrm{a}}$ \\
\hline P. lentiscus & \multicolumn{2}{|c|}{$0.048^{\mathrm{b}}$} & \multicolumn{2}{|c|}{25.6} & \multicolumn{2}{|c|}{$51.3^{a}$} & $61.7^{c}$ \\
\hline s.e.m. & \multicolumn{2}{|c|}{0.003} & \multicolumn{2}{|c|}{0.61} & \multicolumn{2}{|c|}{0.93} & 0.68 \\
\hline Sig. & \multicolumn{2}{|c|}{$*$} & \multicolumn{2}{|c|}{ NS } & \multicolumn{2}{|c|}{$*$} & $* * *$ \\
\hline
\end{tabular}

${ }^{a b c}$ Column means with common superscripts do not differ ( $\left.\mathrm{P}>0.05\right)$; s.e.m. - standard error mean; Sig. - significance level; c - the constant rate of degradation of b (percentage per h); a - water soluble fraction (\%); b - insoluble but fermentable fraction (\%); EDMD - effective dry matter degradability (\%)

NS - non significant; *** $\mathrm{P}<0.001 ; * * \mathrm{P}<0.01 ; * \mathrm{P}<0.05$

The correlation coefficients (r) of the relationship between the chemical composition and gas production or in situ DM degradation parameters from different tree leaves are given in Table 4 and 5.

Table 4 Correlation coefficients (r) of the relationship between the chemical composition and gas production or estimated parameters from different tree leaves

\begin{tabular}{ccccccc}
\hline & \multicolumn{5}{c}{ Chemical constituents } \\
\cline { 2 - 6 } In vitro & CP & ADF & NDF & TCT & BCT & SCT \\
\hline 3 & 0.138 & $-0.721^{* *}$ & $-0.899^{* * *}$ & $-0.630^{*}$ & -0.503 & 0.160 \\
6 & 0.339 & $-0.751^{* *}$ & $-0.848^{* * *}$ & $-0.594^{*}$ & -0.438 & 0.101 \\
12 & 0.153 & $-0.812^{* * *}$ & $-0.835^{* * *}$ & $-0.641^{*}$ & $-0.636^{*}$ & 0.319 \\
24 & 0.020 & $-0.643^{*}$ & $-0.832^{* * *}$ & -0.387 & $-0.786^{* *}$ & 0.527 \\
48 & 0.273 & $-0.691^{*}$ & $-0.609^{*}$ & -0.399 & $-0.600^{*}$ & 0.467 \\
72 & 0.259 & $-0.659^{*}$ & $-0.655^{*}$ & $-0.589^{*}$ & $-0.592^{*}$ & 0.449 \\
96 & 0.148 & $-0.719^{* *}$ & $-0.830^{* * *}$ & $-0.589^{*}$ & $-0.717^{*}$ & 0.473 \\
c & 0.050 & $-0.719^{* *}$ & $-0.816^{* * *}$ & $-0.732^{* *}$ & $-0.406^{\mathrm{s}}$ & -0.038 \\
$\mathrm{a}$ & 0.180 & $-0.505^{\text {NS }}$ & $-0.830^{* * *}$ & $-0.621^{*}$ & -0.505 & 0.165 \\
$\mathrm{~b}$ & 0.151 & $-0.595^{*}$ & $-0.590^{*}$ & -0.409 & $-0.689^{*}$ & 0.572 \\
$\mathrm{a}+\mathrm{b}$ & 0.179 & $-0.602^{*}$ & $-0.654^{*}$ & -0.461 & $-0.690^{*}$ & 0.532 \\
\hline
\end{tabular}

CP - crude protein (g/kg DM); ADF - acid detergent fibre (g/kg DM); NDF - neutral detergent fibre (g/kg DM); TCT - total condensed tannin (g/kg DM); BCT - bound condensed tannin (g/kg DM); SCT - soluble condensed tannin (g/kg DM); c - gas production rate (\%); a - gas production $(\mathrm{mL})$ from quickly soluble fraction; b - gas production $(\mathrm{mL})$ from the insoluble fraction; $\mathrm{a}+\mathrm{b}-$ potential gas production $(\mathrm{mL})$

*** $\mathrm{P}<0.001 ; * * \mathrm{P}<0.01 ; * \mathrm{P}<0.05$

The regression equations describing the relationship between in situ DM degradation and in vitro gas production are given in Table 6. There were no significant relationships between gas production and DM disappearance at 3,6,12, 48 and $72 \mathrm{~h}$ of incubation whereas there were significant relationships at $24 \mathrm{~h}$ and $96 \mathrm{~h}$ incubation times. The gas productions after 24 and $96 \mathrm{~h}$ incubation explained 51.2 and $52.4 \%$ of variation of DM disappearance, respectively. 
Table 5 Correlation coefficients (r) of the relationship between the chemical composition and dry matter disappearance or estimated parameters from different tree leaves

\begin{tabular}{ccccccc}
\hline & \multicolumn{7}{c}{ Chemical constituents } \\
\cline { 2 - 6 } In situ & CP & ADF & NDF & TCT & BCT & SCT \\
\hline 3 & -0.214 & -0.008 & -0.379 & -0.247 & $-0.718^{* *}$ & $0.747^{* *}$ \\
6 & -0.356 & -0.002 & -0.320 & -0.327 & $-0.741^{* *}$ & $0.714^{* *}$ \\
12 & -0.009 & -0.308 & -0.288 & -0.274 & $-0.588^{*}$ & 0.535 \\
24 & -0.373 & -0.143 & -0.389 & -0.192 & $-0.776^{* *}$ & $0.876^{* * *}$ \\
48 & -0.411 & -0.075 & $-0.594^{*}$ & -0.357 & $-0.826^{* * *}$ & $0.819^{* * *}$ \\
72 & -0.410 & -0.178 & -0.469 & -0.145 & $-0.732^{* *}$ & $0.866^{* * *}$ \\
96 & -0.485 & 0.336 & $-0.759^{* *}$ & -0.521 & $-0.897^{* * *}$ & $0.790^{* *}$ \\
C & 0.077 & -0.090 & -0.105 & -0.420 & -0.420 & $0.446^{\text {S }}$ \\
a & -0.388 & -0.091 & -0.219 & -0.133 & $-0.594^{*}$ & $0.678^{* *}$ \\
b & -0.571 & $-0.650^{*}$ & -0.017 & -0.419 & -0.513 & 0.383 \\
EDMD & -0.344 & -0.203 & -0.516 & -0.317 & $-0.837^{* * *}$ & $0.854^{* * *}$ \\
\hline
\end{tabular}

CP - crude protein; ADF - acid detergent fibre; NDF - neutral detergent fibre; TCT - total condensed tannin; BCT bound condensed tannin; SCT - soluble condensed tannin; c - the constant rate of degradation of b (percentage per h); a - water soluble fraction; $\mathrm{b}$ - insoluble but fermentable fraction; EDMD - effective dry matter degradability *** $\mathrm{P}<0.001 ; * * \mathrm{P}<0.01 ; * \mathrm{P}<0.05$

Table 6 Prediction of in situ dry matter (DM) disappearance and estimated parameters from in vitro gas production and estimated parameters

\begin{tabular}{|c|c|c|c|c|}
\hline $\mathrm{Y}$ & Equation and factors used & $\mathrm{R}^{2}$ & RSD & Probability \\
\hline \multicolumn{5}{|l|}{ In situ } \\
\hline 3 & $Y=23.6+0.195$ gas $_{3 h}$ & 11.4 & 1.682 & $>0.05$ \\
\hline 6 & $Y=31.6+0.199$ gas $_{6 \mathrm{~h}}$ & 5.2 & 3.619 & $>0.05$ \\
\hline 12 & $Y=17.6+0.736$ gas $_{12 \mathrm{~h}}$ & 31.3 & 4.366 & $>0.05$ \\
\hline 24 & $Y=17.9+0.772$ gas $_{24 h}$ & 51.2 & 2.730 & $<0.01$ \\
\hline 48 & $Y=41.7+0.416$ gas $_{48 \mathrm{~h}}$ & 33.4 & 2.520 & $<0.05$ \\
\hline 72 & $\mathrm{Y}=46.8+0.379 \mathrm{gas}_{72 \mathrm{~h}}$ & 38.1 & 2.020 & $<0.05$ \\
\hline 96 & $Y=44.1+0.447$ gas $_{96 h}$ & 52.4 & 2.220 & $<0.01$ \\
\hline $\mathrm{C}_{\mathrm{is}}$ & $Y=0.0488-0.118 c_{\text {gas }}$ & 1.9 & 0.007 & $>0.05$ \\
\hline$a_{\text {is }}$ & $\mathrm{Y}=23.9+0.058 \mathrm{a}_{\mathrm{gas}}$ & 0.1 & 1.502 & $>0.05$ \\
\hline$b_{\text {is }}$ & $Y=52+0.007 b_{\text {gas }}$ & 0.0 & 2.990 & $>0.05$ \\
\hline EDMD & $\mathrm{Y}=52.3+1.90 \mathrm{a}_{\mathrm{gas}}$ & 65.7 & 1.830 & $<0.01$ \\
\hline EDMD & $Y=19.4+0.620 b_{\text {gas }}$ & 66.4 & 1.921 & $<0.05$ \\
\hline EDMD & $Y=52.7+70 c_{\text {gas }}$ & 4.3 & 2.898 & $>0.05$ \\
\hline EDMD & $\mathrm{Y}=18.6-0.190 \mathrm{a}_{\mathrm{gas}}+0.64 \mathrm{~b}_{\mathrm{gas}}$ & 65.7 & 1.830 & $<0.01$ \\
\hline EDMD & $\mathrm{Y}=20.5-0.02 \mathrm{a}_{\mathrm{gas}}+0.645 \mathrm{~b}_{\mathrm{gas}}-34.2 \mathrm{c}_{\mathrm{gas}}$ & 66.4 & 1.921 & $<0.01$ \\
\hline EDMD & $\mathrm{Y}=23.5+0.580(\mathrm{a}+\mathrm{b})_{\mathrm{gas}}-43.6 \mathrm{c}_{\mathrm{gas}}$ & 63.7 & 1.881 & $<0.01$ \\
\hline EDMD & $Y=20.4+0.647 b_{\text {gas }}-33.6 c_{\text {gas }}$ & 66.4 & 1.810 & $<0.01$ \\
\hline EDMD & $\mathrm{Y}=22.4+0.545(\mathrm{a}+\mathrm{b})$ gas & 62.3 & 1.818 & $<0.01$ \\
\hline
\end{tabular}

$\mathrm{c}_{\text {is }}$ - rate of DM degradation; $\mathrm{a}_{\text {is }}$ - quickly soluble fraction; $\mathrm{b}_{\text {is }}$ - insoluble but fermentable fraction; EDMD - effective DM degradability; $\mathrm{c}_{\text {gas }}$ - gas production rate; $\mathrm{a}_{\text {gas }}$ - gas production $(\mathrm{mL})$ from quickly soluble fraction; $\mathrm{b}_{\mathrm{gas}}$ - gas production $(\mathrm{mL})$ from the insoluble fraction; $(\mathrm{a}+\mathrm{b})_{\text {gas }}$ - potential gas production $(\mathrm{mL})$

Sig. - significance level

\section{Discussion}

The average chemical composition of the studied samples is consistent with published results, despite differences in location and growth conditions. The chemical composition of $P$. lentiscus was similar to that reported by Decandia et al. (2000). The TCT concentration of $P$. lentiscus was lower than that reported by Silanikove et al. (1996) and Decandia et al. (2000). 
Gas production and most of the estimated parameters showed a negative correlation with NDF, ADF, TCT and BCT. This is consistent with findings of Khazaal \& Ørskov (1994), Tolera et al. (1997) and Abdulrazak et al. (2002). In situ DM disappearance after 48 and $96 \mathrm{~h}$ was negatively correlated with NDF. In situ DM disappearance at all incubation times was negatively correlated with BCT, but positively correlated with SCT except after $12 \mathrm{~h}$ incubation. The NDF and ADF concentrations of tree leaves did not show any significant correlation with DM disappearance and estimated parameters. This result is in agreement with findings of Tolera et al. (1997).

The gas productions were well correlated with DM disappearance after 24 and $96 \mathrm{~h}$ incubation. This is in agreement with findings of Sileshi et al. (1996) but not with that of Blümmel \& Ørskov (1993) who did not find any correlation between these parameters in barley and wheat straw. Beuvinik et al. (1993) and Beuvink \& Kogutk (1993) suggested that the relationship between these parameters varies with type of forage. On the other hand there was no significant relationship between the estimated parameters of gas production and DM degradation of tree leaves in this experiment. This is in agreement with the findings of Beuvink \& Kogutk, (1993) and Blümmel \& Ørskov (1993) who showed that there was no significant correlation between rate of gas production and rate of DM disappearance. On the other hand, Sileshi et al. (1996) found a significant relationship between these parameters. There is no obvious explanation for these anomalies. Differences between the conclusions drawn by different authors may be due to a number of factors such as methodology, the substrates and the physical form used.

Gas production from the insoluble fraction (b) alone explained $66.4 \%$ of the variation of EDMD. The inclusion of gas production from the quickly soluble fraction (a) and the rate constant (c) of gas production in the regression equation did not improve the accuracy of predicting EDMD.

The EDMD of tree leaves was highly correlated $(\mathrm{r}=0.790, \mathrm{P}<0.001)$ to potential in vitro gas production. This is in agreement with Blümmel \& Ørskov (1993), Khazaal et al. (1993) and Sileshi et al. (1996). The highly significant relationship between gas production and DM disappearance after 24 and $96 \mathrm{~h}$ incubation suggests that either method could be used to estimate the nutritive value of such tree leaves. Khazaal et al. (1994) reported that the in situ method should be used with caution when estimating the nutritive value of feed containing high levels of phenolic compounds. The potential negative effect of phenolic compounds on microbial fermentation is unlikely to be detected by the in situ method. In this regard in vitro methods are more reliable in detecting inhibitory compounds in feeds. The in vitro gas production method is a closed system with a limited supply of rumen liquor. Any anti-nutritive compound is likely to affect the activity of the rumen microbes. On the other hand, the in situ method is associated with a dilution effect which results from an open system with a wider rumen environment and copious supply of rumen fluid to nylon bag content (Apori et al., 1998). This is why the DM disappearance and some estimated parameters showed a positive correlation with SCT in this experiment (Table 5).

A low relationship (especially at 3, 6, 12, 48 and $72 \mathrm{~h}$ incubation times) between gas production and DM disappearance may be due to the interference of tannin in the leaves. The relationship between the two techniques might be increased when tannin-containing tree leaves were incubated in the presence of polyethylene glycol (PEG) since there is a significant negative correlation between gas production and TCT or BCT contents. Some studies clearly showed that PEG supplementation increased gas production (Getachew et al., 2001; Getachew et al., 2002; Seresinhe \& Iben, 2003). However, tree leaves did not give the same response to PEG supplementation, possibly due to differences in the chemical composition of tannins in tree leaves. Although the increase in the gas production of Acacia cyanophylla was $10.3 \mathrm{~mL}$, the increase in the gas production of $C$. calothyrsus was $22 \mathrm{~mL}$ when they were incubated in the presence of PEG (77 mg) (Getachew et al., 2001). More studies are required to test the effect of PEG supplementation on the relationship between in vitro gas and in situ DM degradation.

This study revealed a general problem of overestimation of degradability by the nylon bag technique. Overestimation is especially noticeable at short incubation times. The ability to use in vitro gas production methods to study the kinetics of degradation of tannin containing forage instead of the in situ technique would have advantages, including avoiding the error associated with loss of small particles through the pores of the nylon bag.

\section{Conclusion}

There were significant relationships between parameters obtained using two techniques; the in situ digestion and in vitro gas production. Therefore, it was concluded that DM disappearance parameters of 
tannin-containing tree leaves may be predicted from in vitro gas production parameters. The relationship between parameters might be increased when tree samples were incubated in the presence of PEG. Therefore, more investigations are required to see the effect of PEG supplementation on the improvement of the relationship between in vitro gas and in situ DM degradation.

\section{References}

Abdulrazak, S.A., Fujihara, T., Ondilek, J.K. \& Ørskov, E.R., 2000. Nutritive evaluation of some Acacia tree leaves from Kenya. Anim. Feed Sci. Technol. 85, 89-98.

AOAC, 1990. Official Method of Analysis. (15th ed.). Association of Official Analytical Chemist, Washington D.C., USA.

Apori, S.O., Castro, F.B., Shand, W.J. \& Ørskov, E.R., 1998. Chemical composition, in sacco degradation and in vitro gas production of some browse plants. Anim. Feed Sci. Technol. 76, 129-137.

Beuvink, J.M.W. \& Kogutk, J., 1993. Modelling gas production kinetics of grass silages incubated with buffered rumen fluid. J. Anim. Sci. 71, 1041-1046.

Beuvink, J.M.W., de Visser, H. \& Klop, A., 1993. In vitro gas production kinetics of different maize products: A comparison to nylon bag degradation kinetics. In: Measuring and modelling in vitro gas production kinetics to evaluate ruminal fermentations of feedstuffs. Ed. Beuvink, J.M.W., DLOResearch Institute for Livestock Feeding and Nutrition Report, Lelystad, The Netherlands. pp. 41-51.

Blummel, M. \& Ørskov, E.R., 1993. Comparison of in vitro gas production and nylon bag degradability of roughages in predicting of food intake in cattle. Anim. Feed Sci. Technol. 40, 109-119.

Decandia, M., Sitzia, M., Cabiddu, A., Kababya, D. \& Molle, G., 2000. The use of polyethylene glycol to reduce the anti-nutritional effects of tannins in goats fed woody species. Small Rumin. Res. 38, 157164.

Dewhurst, R.J., Hepper, D. \& Webster, A.J.F., 1995. Comparison in sacco and in vitro techniques for estimating the rate and extent of rumen fermentation of a range of dietary ingredients. Anim. Feed Sci. Technol. 51, 211-229.

Getachew, G., Makkar, H.P.S. \& Becker, K., 2001. Method of polyethylene glycol application to tannincontaining browses to improve microbial fermentation and efficiency of microbial protein synthesis from tannin-containing browses. Anim. Feed Sci. Technol. 92, 51-57.

Getachew, G., Makkar, H.P.S. \& Becker, K., 2002. Tropical browses: contents of phenolic compounds, in vitro gas production and stoichiometric relationship between short chain fatty acid and in vitro gas production. J. Agric. Sci., Camb. 139, 341-352.

Khazaal, K., Boza, J. \& Ørskov, E.R., 1994. Assessment of phenolics-related anti-nutritive effects in Mediterranean browse. A comparison between the use of the in vitro gas production technique with or without insoluble polyvinylpolypyrrolidone or nylon bag. Anim. Feed Sci. Technol. 49, 133-149.

Khazaal, K., Markantonatos, X., Nastis, A. \& Ørskov, E.R., 1993. Changes with maturity in fibre composition and levels of extractable polyphenols in Greek browse: Effect on in vitro gas production and in sacco dry matter degradation. J. Sci. Food Agric. 63, 237-244.

Krishnamoorthy, H., Steingass, H. \& Menke, K.H., 1991. Preliminary observations on the relationships between gas production and microbial protein synthesis in vitro. Arch. Anim. Nutr. 41, 521-526.

Makkar, H.P.S., Blümmel, M. \& Becker, K., 1995. Formation of complexes between polyvinyl pyrrolidones or polyethylene glycols and their implication in gas production and true digestibility in vitro techniques. Br. J. Nutr. 73, 897-913.

Mehrez, A.Z. \& Ørskov, E.R., 1977. A study of artificial fibre bag technique for determining the digestibility of feeds in the rumen. J. Agric. Sci., Camb. 88, 645-650.

Menke, H.H. \& Steingass, H., 1988. Estimation of the energetic feed value obtained from chemical analysis and in vitro gas production using rumen fluid. Anim. Res. Dev. 28, 7-55.

Menke, K.H., Raab, L., Salewski, A., Steingass, H., Fritz, D. \& Schneider, W., 1979. The estimation of the digestibility and metabolisable energy content of ruminant feedingstuffs from the gas production when they are incubated with rumen liquor. J. Agric. Sci., Camb. 93, 217-222.

Ørskov, E.R., 1989. Recent advances in evaluation of roughages as feeds for ruminants. In: Advances in Animal Nutrition. Ed. Farell, D.J., University of New England Printery, Armidale. pp. 102-108.

Ørskov, E.R. \& McDonald, P., 1979. The estimation of protein degradability in the rumen from incubation measurements weighed according to rate of passage. J. Agric. Sci., Camb. 92, 499-503. 
Pearse, E.S. \& Hartley, H.O., 1966. Biometrika tables for statisticians. Vol.1. Cambridge University Press.

Seresinhe, T. \& Iben, C., 2003. In vitro quality assessment of two tropical shrub legumes in relation to their extractable tannins content. J. Anim. Physiol. Anim. Nutr. 87, 109-115.

Silanikove, N., Gilboa, N., Perevolotsky, Z. \& Nitsan, Z., 1996. Goats fed tannin containing leaves do not exhibit toxic syndromes. Small Rumin. Res. 21, 195-201.

Sileshi, Z., Owen, E., Dhanoa, M.S. \& Theodorou, M.K., 1996. Prediction of in situ rumen dry matter disappearance of Ethiopian forages from an in vitro gas production technique using a pressure transducer, chemical analyses or in vitro digestibility. Anim. Feed Sci. Technol. 61, 73-87.

Stastica, 1993. Stastica for windows release 4.3, StatSoft, Inc. Tulsa, OK

Tolera, A., Khazaal, K. \& Ørskov, E.R., 1997. Nutritive evaluation of some browses species. Anim. Feed Sci. Technol. 67, 181-195.

Van Soest, P.J., Robertson, J.D. \& Lewis, B.A., 1991. Methods for dietary fiber, neutral detergent fiber and non-starch polysaccharides in relation to animal nutrition. J. Dairy Sci. 74, 3583-3597. 